\title{
Understanding the distribution and fate of nitrogen and phosphorus in OVERSEER $®$
}

\author{
D.R. SELBIE, N.L. WATKINS, D.M. WHEELER and M.A. SHEPHERD \\ AgResearch, Ruakura Research Centre, PB 3123, Hamilton \\ diana.selbie@agresearch.co.nz
}

\begin{abstract}
OVERSEER $^{\circledR}$ Nutrient Budgets (Overseer) is an agricultural management support tool that examines the flow of nutrients in a farming system. There is increasing pressure from a range of users for transparency of the way Overseer functions, particularly the modelling of nitrogen $(\mathrm{N})$ and phosphorus $(\mathrm{P})$ loss to water. The aim of this paper is to provide a conceptual description of the way Overseer models the distribution and fate of $\mathrm{N}$ and $\mathrm{P}$ in a pastoral system, to support user understanding and correct model use. The core of Overseer is a nutrient budget, which accounts for the flow of nutrient into, around and off the farm. The key strength of Overseer is its ability to model these nutrient transfers around the farm, identifying how much, where and when nutrients move. Other parts of the model then estimate the fate of these nutrients. Nitrogen and P cycle differently around the farm, which is reflected in the way they are modelled. This paper is intended to be a support document for understanding the way Overseer models $\mathrm{N}$ and $\mathrm{P}$, and where more detailed information is required, it may be found on the Overseer website (www.overseer.org.nz).
\end{abstract}

Keywords: Nutrient budget, model, leaching, run-off

\section{Introduction}

Nitrogen $(\mathrm{N})$ and phosphorus $(\mathrm{P})$ are essential nutrients for plant growth and are often limiting in agricultural production. However, the loss of $\mathrm{N}$ and $\mathrm{P}$ from agricultural land has been identified as a common cause of deterioration of water quality (McDowell et al. 2004; Gruber \& Galloway 2008). Aquatic systems in which $\mathrm{N}$ and $\mathrm{P}$ are limiting are usually sensitive to minor increases in these nutrients and this can lead to significant algal/macrophyte growth in waterways (McDowell et al. 2004). The amount of P loss, typically $1-2 \mathrm{~kg} / \mathrm{ha} / \mathrm{yr}$, which may have an impact on water quality, is small in agronomic terms; in contrast, $\mathrm{N}$ loss $(20-60 \mathrm{~kg} / \mathrm{ha} / \mathrm{yr})$ represents a significant agronomic loss as well as potentially harming the environment. Quantifying N and P loss at the farm level is generally difficult, because of the need to capture all of the $\mathrm{N}$ and $\mathrm{P}$ leaving the farm and the disadvantages of many of the existing measurement techniques (Lilburne et al. 2012). Farm-scale models may be used for estimating $\mathrm{N}$ and
$\mathrm{P}$ loss, and typically involve modelling interactions between farm inputs of $\mathrm{N}$ and $\mathrm{P}$ with rainfall, soil type and topography.

The use of OVERSEER ${ }^{\circledR}$ Nutrient Budgets (Overseer) as a tool to model nutrient losses has gained increasing attention in recent years. Model users include farmers, consultants, nutrient advisors, scientists, policy developers and regulators. With increasing use of Overseer from a range of users, an understanding of the way the model works is required for appropriate application and correct use. The aim of this paper is to provide a conceptual description of how $\mathrm{N}$ and $\mathrm{P}$ are modelled in Overseer with particular emphasis on $\mathrm{N}$ leaching and $\mathrm{P}$ run-off in a pastoral system.

\section{Overview of OVERSEER ${ }^{\circledR}$ Nutrient Budgets What is Overseer?}

Overseer is an agricultural management support tool that examines the flow of nutrients in a farming system. A "model", or representation of a farm system, enables the effects of management decisions to be evaluated at a scale which is appropriate and realistic for farmers, consultants, policy makers and scientists. The Overseer model is based on a nutrient budget, which is an account of the nutrient inputs and outputs across a farm (or block) boundary (Figure 1). Nutrients enter the farm, are then distributed around the farm between management blocks, cycled within the block, or removed from the farm. Through Overseer the user is able to identify pasture fertiliser nutrient requirements, effluent loadings, potential nutrient losses in run-off and leaching, and greenhouse gas emissions as well as mitigation options to reduce losses and improve nutrient use efficiency (Wheeler et al. 2003).

\section{Nutrient distribution}

It is important to appreciate that Overseer operates at two scales; at the farm and at the block level (Figure 2 ). Whereas many models focus on the fate of nutrients in a paddock/management block (e.g. leaching, runoff), Overseer's key strength is that it models across the whole farm, including estimating transfers of nutrients between blocks (e.g., facilitated by the animal). Furthermore, the sum of blocks set up by the user does not equal the farm; Overseer also accounts 
for nutrients that move between blocks and structures such as the dairy, feed pad or effluent store. Much of the underpinning science has been focused on correctly representing these transfers around the farm to identify how much nutrient moves where and when. Once this is known, then other models can estimate the fate of these nutrients.

Farm scale refers to the land area covered by a management unit of interest e.g., the legal farm boundary. However, the land area does not need to be contiguous; rather it should be an integrated operational unit e.g., a dairy farm and support block can be set up as a single unit. Farm scale inputs are those that relate to farm type, enterprises and structures on the farm, animal performance and feed data. Block scale is defined as an area of the farm that has common physical and/or management attributes e.g., different soil types or areas where effluent is applied. Again, blocks do not have to be geographically linked. There may be multiple blocks which make up a farm in Overseer. Blocking characteristics (and inputs) include topography, climate conditions, soil type, fertiliser and effluent management and irrigation (Wheeler \& Shepherd 2012) (Figure 2).

\section{Source and distribution of excreta in a pastoral block}

Overseer uses animal metabolisable energy (ME) requirements, less that supplied as supplements and crops, to estimate pasture feed intake. Nitrogen and $\mathrm{P}$ intakes are then estimated from the nutrient content of the feed (pasture, supplements and crops). The ME requirement of animals is derived from the production information input by the user. Thus differences in feed quality and feed $\mathrm{N}$ and $\mathrm{P}$ concentrations are included in the estimate of animal nutrient intakes.

The proportion of $\mathrm{N}$ and $\mathrm{P}$ excreted is derived from a balance between intake, maintenance requirements and removal in products from the farm. Typically, $60-90 \%$ of the ingested $\mathrm{N}$ and $\mathrm{P}$ are excreted, with most of the $\mathrm{N}$ in urine, and the $\mathrm{P}$ in dung (Haynes \& Williams 1993).

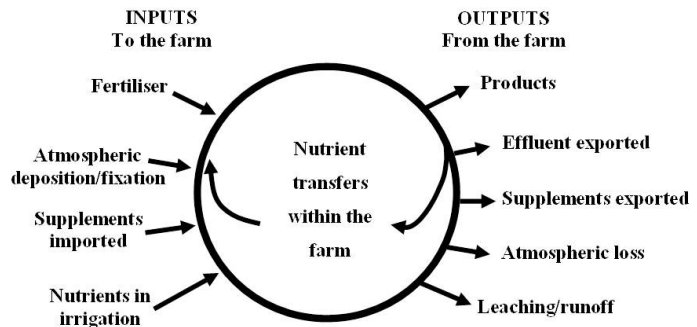

Figure 1 Schematic diagram of a farm nutrient budget in Overseer.
For $\mathrm{N}$, the partitioning depends on the $\mathrm{N}$ content of the diet. Excreted $\mathrm{N}$ and $\mathrm{P}$ is calculated and partitioned between dung and urine, on a monthly basis. The majority of the $\mathrm{N}$ and $\mathrm{P}$ ingested is returned to pasture in the urine and dung (when applied to the soil surface). The remainder is distributed between structures and laneways, and captured as effluent which is then spread back on the pasture. Once the distribution is known, the fate of the returned $\mathrm{N}$ and $\mathrm{P}$ can be modelled as described below. A more detailed overview of the Animal sub-model, is described in the Introduction chapter of the Overseer Technical Manual (Wheeler \& Shepherd 2012).

\section{Fate of nitrogen in a pastoral block}

At the block level, the $\mathrm{N}$ model is split into Urine and Background sub-models (Figure 3). The Urine submodel deals with $\mathrm{N}$ applied to the paddock in urine patches, and the Background sub-model deals with dung, fertiliser, effluent and other organic additives to the area of the paddock in between urine patches. Leached $\mathrm{N}$ is the $\mathrm{N}$ which moves below the root zone in drainage, and is calculated on a monthly timestep which allows the effects of timing of drainage and management changes to be captured. Of the $\mathrm{N}$ that is applied to a block, only a proportion is potentially leached each month, and the remaining $\mathrm{N}$ is distributed between competing processes. Uptake and immobilisation processes recycle $\mathrm{N}$ within the block, whereas volatilisation, denitrification and leaching pathways result in $\mathrm{N}$ leaving the block and farm, as environmental losses. Some of the $\mathrm{N}$ uptake ends up in animal product leaving the farm.

The Background $\mathrm{N}$ sub-model is based on $\mathrm{N}$ received from non-urine inputs in surface applied, plant and soil sources (Cichota et al. 2010). Sources are split between slow release (organic $\mathrm{N}$ ) and quick release (mineral $\mathrm{N}$ ) pools. In this system the $\mathrm{N}$ added is used relatively

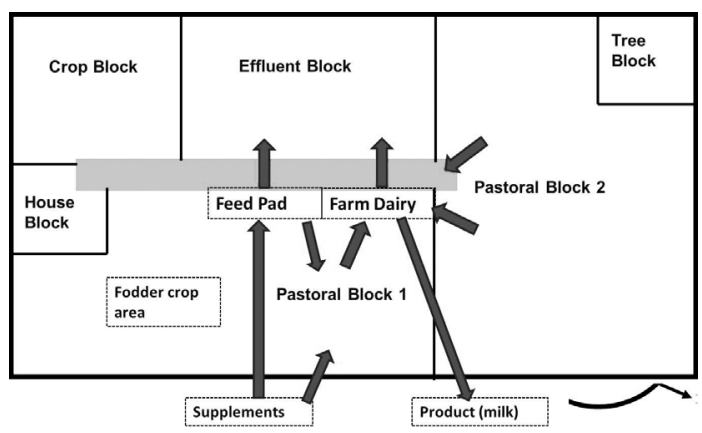

Figure 2 Schematic representation of a dairy farm in Overseer. Arrows indicate nutrient transfer pathways, between blocks and structures, with only some shown for clarity. 
efficiently by the pasture, thus reducing the potential for $\mathrm{N}$ loss. As a result, the $\mathrm{N}$ leaching losses from the Background pool can be considered akin to a cut and carry system where much of the added $\mathrm{N}$ is captured by the pasture. In such systems, $\mathrm{N}$ leaching losses are typically low (e.g., Simmelsgaard 1998; Ball \& Ryden 1984). A more detailed description of $\mathrm{N}$ leaching in the pastoral $\mathrm{N}$ model is provided in the Overseer Technical Note No.5 (Shepherd \& Wheeler 2012).

The Urine sub-model is based on an $\mathrm{N}$ balance of a "typical" urine patch with an $\mathrm{N}$ loading rate of 750 $\mathrm{kg} \mathrm{N} / \mathrm{ha}$ for a dairy cow, which is within the range suggested by Haynes \& Williams (1993). Of the urine $\mathrm{N}$ applied to the block, some may be removed in pasture uptake, which is based on a growth model dependent on moisture, temperature and solar radiation. Other competing $\mathrm{N}$ processes for urine $\mathrm{N}$ (which reduce the potential $\mathrm{N}$ leaching) include immobilisation, volatilisation, and denitrification.

The quantity of urine deposited in a month is multiplied by the estimated proportion that will leach during the drainage period (mainly the winter period). Summing this for each month's urinary $\mathrm{N}$ deposition gives the annual $\mathrm{N}$ leaching load for that block. This assumption is tested or "validated" by comparing modelled estimates with results of block-scale field trials (Shepherd \& Wheeler 2012). Urine patches of sheep, deer, cattle (male) and goats produce a smaller load of urine $\mathrm{N}(\mathrm{kg} \mathrm{N} / \mathrm{ha}$ ) than that of dairy cows (Haynes \& Williams 1993), and thus a scaling adjustment is made to the amount of $\mathrm{N}$ leached.

The relationship between drainage and the soil available water capacity (AWC) is the main driver for $\mathrm{N}$ leaching in the pastoral urine $\mathrm{N}$ model. Overseer has a daily water balance model which calculates the amount of drainage based on climate and irrigation inputs. The amount of $\mathrm{N}$ leaching is related to the number of "pore volumes" (or times the soil is "flushed") that drain through the soil. As well as drainage, $\mathrm{N}$ leaching is sensitive to soil AWC, which is specific to the soil

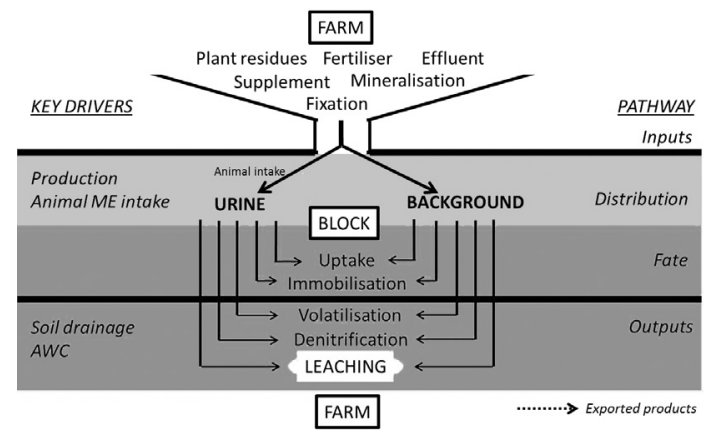

Figure 3 The fate of nitrogen $(\mathrm{N})$ in a pastoral block in Overseer. description (type, group or order input). Shallow soils will tend to have a low AWC and will be flushed several times during the drainage season, hence a greater proportion of the $\mathrm{N}$ applied will be leached. Drainage and AWC are described in detail in the Hydrology section of the Overseer Technical Manual (Wheeler \& Rutherford 2012).

Management factors that affect the amount of $\mathrm{N}$ leaching depend mostly on (1) the amount of urine $\mathrm{N}$ which is available to be leached ( $\mathrm{N}$ added less removal), and (2) the proportion of that $\mathrm{N}$ that is leached, which is determined by the volume and timing of soil drainage. The main $\mathrm{N}$ leaching risk period is late autumn and winter when the soil is draining. Recent studies have shown that urine $\mathrm{N}$ deposited during the late summer and early autumn period contributes to $\mathrm{N}$ leaching during winter (Shepherd et al. 2010). Fertiliser and effluent $\mathrm{N}$ inputs are additional to urine $\mathrm{N}$, and are inefficient in terms of pasture uptake when applied on top of a urine patch (Silva et al. 1999). Irrigation effects on $\mathrm{N}$ leaching are complex: uptake of urine $\mathrm{N}$ by pasture may be increased (and leaching risk reduced) by irrigating in dry periods; however, more pasture will be grown, consumed and $\mathrm{N}$ excreted in urine patches, compared to an un-irrigated block. Additionally, if irrigation is not scheduled correctly, and produces extra drainage, leaching will be increased. Reducing urine $\mathrm{N}$ inputs by wintering animals off-farm, and reducing "leachability" of urine $\mathrm{N}$ by applying DCD nitrification inhibitor are two mitigation strategies to reduce $\mathrm{N}$ leaching.

\section{Fate of phosphorus in a pastoral block}

Whereas the focus of $\mathrm{N}$ loss is on urinary $\mathrm{N}$, important sources of $\mathrm{P}$ within an agricultural system include fertiliser, effluent, supplements and excreted animal dung. Unlike $\mathrm{N}$, the amount of $\mathrm{P}$ in animal urine is insignificant. The $\mathrm{P}$ model within Overseer is a calibrated risk model of $\mathrm{P}$ loss to second order streams, which is described by McDowell et al. (2005). Phosphorus inputs are divided into: Incidental (recent

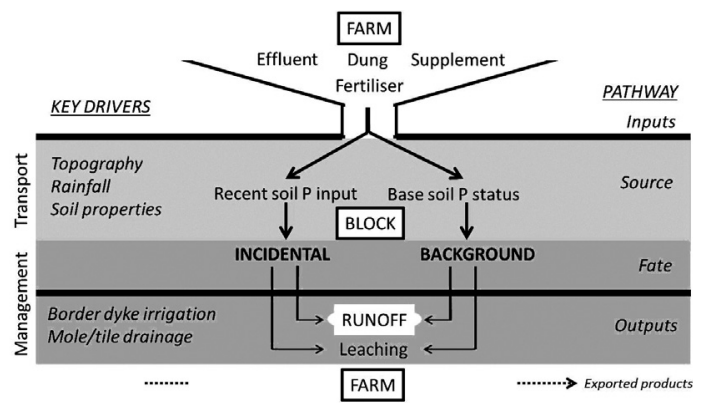

Figure 4 The fate of phosphorus $(\mathrm{P})$ in a pastoral block in Overseer 
soil $\mathrm{P}$ inputs) and Background (base soil $\mathrm{P}$ inputs) (Figure 4). Incidental $P$ arises from fertiliser and effluent $\mathrm{P}$ loss, whereas Background $\mathrm{P}$ arises from soil P loss (McDowell et al. 2005). The sum of both these sources of $\mathrm{P}$ loss is referred to as total $\mathrm{P}$ lost to water $(\mathrm{kg} \mathrm{P} / \mathrm{ha} /$ yr). The P model also takes into account an estimate of direct deposition of animal excreta into streams on unfenced blocks, and the impact of deer through fence line pacing and wallows. The model assumes that sources of loss such as direct runoff from raceways or stream crossings to water bodies are minimal. It does not take into account $\mathrm{P}$ lost in sediment due to erosion.

The principal aim of the $\mathrm{P}$ model is to capture situations where there is likely to be connectivity between $\mathrm{P}$ sources and waterways, primarily due to overland or subsurface flow. This connectivity is provided by transport drivers and these are the key determinants of the distribution and fate of $\mathrm{P}$ inputs (Figure 4).

Topography is one of the key transport drivers of P loss, and Overseer uses a subjective weighting to separate slopes. A greater weighting is given to steeper slopes: flat (0.15), rolling (0.5), easy $(0.75)$ and steep (1.0) (McDowell et al. 2005). Another key transport driver is rainfall, in particular when precipitation exceeds infiltration rate and overland flow results. Soil properties strongly influence infiltration rate and hence the potential for overland flow. Soil properties can be broken down into two factors: (1) soil textural properties and (2) soil structural properties. Soil textural properties are used as a basis for determining drainage potential, for example sandy soils have greater drainage potential than clay soils. Soil structural properties are used as a basis for determining the potential for soil damage to influence soil hydrology, for example a soil with a high potential for slaking will probably impede soil drainage (McDowell et al. 2005). Taking into account both soil textural and structural factors, a hydrologic class for each soil is determined, where a large value indicates that a soil is more susceptible to overland flow (McDowell et al. 2005).

Management drivers are conditions under the control of the farmer that can influence the ability of $\mathrm{P}$ to be transported (Figure 4). Three major management drivers of background $\mathrm{P}$ loss are Olsen $\mathrm{P}$, mole/tile drains and border dyke irrigation. Soil $\mathrm{P}$ loss can be accelerated once Olsen $\mathrm{P}$ is above the biological optimum for pasture growth (McDowell et al. 2005). Mole/tile drains provide a transport mechanism for topsoil $\mathrm{P}$ loss directly to streams. If mole/tile drains are selected by the user, an additional $0.3 \mathrm{~kg} \mathrm{P} / \mathrm{ha} /$ year is added to the background $\mathrm{P}$ loss (Monaghan et al. 2003). The use of border dyke irrigation is one of the most potentially significant management drivers of $\mathrm{P}$ loss. $\mathrm{P}$ loss from border dyke irrigation is estimated by taking into consideration Olsen P level, hydrological class and surplus rainfall. Deer farms have additional data entry requirements within Overseer, to account for deer pacing fence lines and creating wallows (McDowell et al. 2008). Both these activities increase the probability of $\mathrm{P}$ being potentially transported.

Major management drivers that influence incidental $\mathrm{P}$ loss are concentration, rate and timing of fertiliser and/or effluent applications, and the form of these applications. The speed of effluent application is also an important management driver. Within Overseer speed is taken into account through the application depth selected by the user. The smaller the application per unit time the less the risk would be of soil saturation and overland flow occurring.

The risk of timing of fertiliser and effluent application leading to overland flow is ranked for each region for every month of the year. A month is deemed as high risk for overland flow when the potential for saturation excess is $>60 \%$ (McDowell et al. 2005). Modifying the timing of $\mathrm{P}$ fertiliser or effluent can have a significant impact on $\mathrm{P}$ losses. Following the application of fertiliser or effluent, the risk of $\mathrm{P}$ loss generally decreases exponentially with time as P interacts with the soil (McDowell et al. 2004). Modifying the type of $\mathrm{P}$ fertiliser applied, such as using a slow-release $P$ fertiliser like RPR, can also significantly decrease P losses.

The fate of the incidental and background $\mathrm{P}$ loss is divided into $\mathrm{P}$ loss via run-off or leaching, $\mathrm{P}$ loss through animals having direct access to streams/drains and P loss through system losses such as border dyke irrigation and septic tank "outwash" and direct pond discharge. The "farm sources" output reported in Overseer is the estimated P loss from farm structures, such as pads and raceways.

Sources of P loss are generally easier to identify and mitigate than sources of $\mathrm{N}$ loss. The loss of $\mathrm{P}$ is typically linked to critical source areas (CSAs). CSAs are defined as areas where high concentrations of $\mathrm{P}$ are found and where the risk of flow/movement of this $\mathrm{P}$ is also high, for example stock camps established on hill slopes. Mitigation options centre on either reducing the amount of $\mathrm{P}$ in CSAs, or breaking the connectivity between the source and the water body. Further improvements of models to better predict CSAs will provide more targeted $\mathrm{P}$ mitigation strategies, which will aid the management of P loss from farms (e.g., Stafford \& Peyroux 2013). 


\section{Conclusions}

A description of the Overseer pastoral model for $\mathrm{N}$ and $P$ has shown that:

- Overseer models N and P distribution across the farm in blocks and structures such as the farm dairy and feed pads, and displays this using the base concept of a nutrient budget.

- Once we know how much N or P, where and when it is deposited, then its fate can be further modelled.

- Approaches for modelling $\mathrm{N}$ and $\mathrm{P}$ loss are different because their loss mechanisms and drivers are different.

Overseer is a useful tool for modelling the complex interactions of nutrients in a pastoral system. By understanding the transfers and losses of $\mathrm{N}$ and $\mathrm{P}$, and how they are modelled, the application of Overseer reports as well as on-farm nutrient management may be improved.

\section{ACKNOWLEDGEMENTS}

OVERSEER ${ }^{\circledR}$ is a registered trademark and is jointly owned by FANZ, MPI and AgResearch. Funding provided under AgResearch's Core Overseer Capability Building project is gratefully acknowledged. The authors wish to thank Mike Freeman and Bob Longhurst for reviewing the manuscript.

\section{REFERENCES}

Ball, P.; Ryden, J. 1984. Nitrogen relationships in intensively managed temperate grasslands. Plant and Soil 76: 23-33.

Cichota, R.; Brown, H.; Snow, V.O.; Wheeler, D.M.; Hedderley, D.; Zyskowski, R.; Thomas, S. 2010. A nitrogen balance model for environmental accountability in cropping systems. New Zealand Journal of Crop and Horticultural Science 38: 189-207.

Gruber, N.; Galloway, J.N. 2008. An Earth-system perspective of the global nitrogen cycle. Nature 451: 293-296.

Haynes, R.J.; Williams, P.H. 1993. Nutrient cycling and soil fertility in the grazed pasture ecosystem. Advances in Agronomy 49: 119-199.

Lilburne, L.; Carrick, S.; Webb, T.; Moir, J. 2012. Computer-based evaluation of methods to sample nitrate leached from grazed pasture. Soil Use and Management 28: 19-26.

McDowell, R.W.; Biggs, B.J.F.; Sharpley, A.N.; Nguyen, L. 2004. Connecting phosphorus loss from agricultural landscapes to surface water quality. Chemistry and Ecology 20: 1-40.

McDowell, R.W.; Monaghan, R.M.; Wheeler, D.M. 2005. Modelling phosphorus losses from pastoral farming systems in New Zealand. New Zealand Journal of Agricultural Research 48: 131-141.
McDowell, R.W.; Wheeler, D.M.; de Klein, C.A.M.; Rutherford, A.J. 2008. Deer and environment: Overseer ${ }^{\circledR}$ upgrade. Proceedings of the New Zealand Grassland Association 70: 95-99.

Monaghan, R.M.; Paton, R.J.; Drewry, J.J. 2003. Nitrogen and phosphorus losses in tile drainage from a cattle-grazed pasture in eastern Southland. New Zealand Journal of Agricultural Research 45: 197-205.

Shepherd, M.; Phillips, P.; Snow, V.; Glassey, C. 2010. Mitigating nitrate leaching in dairy systems - which periods of urine deposition should we be targeting? pp. 174-182 In: Farming's Future: Minimising Footprints and maximising margins. Eds. Currie, L.D.; Lindsay, C.L. Occasional Report No. 23. Fertilizer \& Lime Research Centre, Massey University, Palmerston North.

Shepherd, M.A.; Wheeler, D.M. 2012. Technical Note No.5 (August 2012): Changes to the pastoral N model. Accessed from http://www.overseer.org.nz/ OVERSEERMode1/Information/Technicalnotes.aspx on 1 June 2013. pp.18

Silva, R.G.; Cameron, K.C.; Di, H.J.; Hendry, T. 1999. A lysimeter study of the impact of cow urine, dairy shed effluent, and nitrogen fertiliser on nitrate leaching. Australian Journal of Soil Research 37: 357-369.

Simmelsgaard, S.E. 1998. The effect of crop, N-level, soil type and drainage on nitrate leaching from Danish soil. Soil Use and Management 14: 30-36.

Stafford, A.; Peyroux, G. 2013. Clearview (Balance PGP) - A first look at new solutions for improving nitrogen and phosphorus management. In: Accurate and efficient use of nutrients on farms. Eds. Currie, L.D.; Christensen, C.L. Occasional Report No. 26. Fertilizer and Lime Research Centre, Massey University, Palmerston North, New Zealand. http:// flrc.massey.ac.nz/publications.html.

Wheeler, D.M.; Ledgard, S.F.; de Klein, C.A.M.; Monaghan, R.M.; Carey, P.L.; McDowell, R.W.; Johns, K.L. 2003. OVERSEER® nutrient budgets - moving towards on-farm resource accounting. Proceedings of the New Zealand Grassland Association 65: 191-194.

Wheeler, D.M.; Rutherford, J.C. 2012. Hydrology. Technical Manual for the description of the OVERSEER ${ }^{\circledR}$ model. Accessed 1 June 2013 from www.overseer.org.nz/OVERSEERModel/ Information/Technicalmanual pp.33

Wheeler, D.M.; Shepherd, M.A. 2012. Introduction. Technical Manual for the description of the OVERSEER ${ }^{\circledR}$ model. Accessed 1 June 2013 from www.overseer.org.nz/OVERSEERModel/ Information/Technicalmanual pp.31 
